1969

\title{
On Assessing the Court in History: Some Comments on the Roper and Burke Articles
}

\author{
R. Kent Newmyer \\ University of Connecticut School of Law
}

Follow this and additional works at: https://opencommons.uconn.edu/law_papers

Part of the Judges Commons, and the Legal History Commons

\section{Recommended Citation}

Newmyer, R. Kent, "On Assessing the Court in History: Some Comments on the Roper and Burke Articles" (1969). Faculty Articles and Papers. 119.

https://opencommons.uconn.edu/law_papers/119 


\section{HEINONLINE}

Citation: 21 Stan. L. Rev. 540 1968-1969

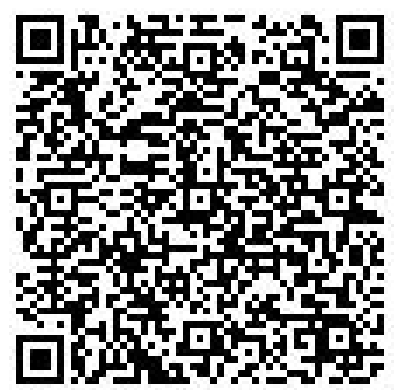

Content downloaded/printed from

HeinOnline (http://heinonline.org)

Mon Aug 15 17:13:35 2016

-- Your use of this HeinOnline PDF indicates your acceptance of HeinOnline's Terms and Conditions of the license agreement available at http://heinonline.org/HOL/License

-- The search text of this PDF is generated from uncorrected OCR text.

-- To obtain permission to use this article beyond the scope of your HeinOnline license, please use:

https://www.copyright.com/ccc/basicSearch.do?

\&operation $=$ go\&search Type $=0$

\&lastSearch $=$ simple\&all $=$ on\&titleOrStd $N o=0038-9765$ 


\title{
On Assessing the Court in History: Some Comments on the Roper and Burke Articles
}

\author{
Kent Newmyer*
}

The idea that there is a symbiotic relationship between American culture and American law is not new. But American historians, as Paul Murphy reminds us, ${ }^{1}$ have been reluctant to explore this relationship. Mr. Roper and Mr. Burke are not among the laggards. Each from his own point of departure sets out to explore the relationship between law and culture. Both agree that considerations of politics, economics, and morality bear on the judges, influence judicial strategy, and shape Supreme Court decisions; both agree that the decisions of the Court, in turn, leave a cultural mark that often goes beyond the formal rule of law established.

There are, however, some special problems facing the historian who attempts to put law in a cultural context. The Supreme Court lives in the world, to be sure. Judges make law, not find it. When they do they are swayed by ordinary human passions and are inclined to political, social, and economic predilections deriving from their own background and experience. ${ }^{2}$ Yet there is an important qualification. The Court is not a legislature. Its procedures and intellectual assumptions are not those of Congress. Judges have biases that shape policy decisions, but they also have commitments to the institutional tradition of the Court and to the methodology of the law. However much the Court is part of the real world of interests and political power, it does not cease being a court of law. The obligation of the constitutional historian is twofold in this regard. He must go beyond the narrow, formal view of the law into the realm of politics, economics, and intellectual history. At the same time, he must do justice to the legal side of the Court; he must show how, within the limits of unique legal institutions, the Justices accomplish their cultural mission. With these observations as a point of critical departure, let me turn to the essays of Mr. Roper ${ }^{3}$ and Mr. Burke."

- B.A. I952, Doane College; Ph.D. 1959, University of Nebraska. Associate Professor of History, University of Connecticut.

I. Murphy, Time to Reclaim: The Current Challenge of American Constitutional History, 69 Am. Hist. Rev. 64 ( 1963$)$.

2. See generally Deutsch, Neutrality, Legitimacy, and the Supreme Court: Some Intersections Between Law and Political Science, 20 STAN. L. REv. 169 (1968).

3. Roper, In Quest of Judicial Objectivity: The Marshall Court and the Legitimation of Slavery, 2x STAN. L. REv. 532 (1969). $(1969)$.

4. Burke, The Cherokee Cases: A Study in Law, Politics, and Morality, 2I Stan. L. Rev. 500 
I agree with much of Mr. Roper's article, but there are substantial parts of his argument and conclusions that leave me in doubt. First, let me hazard a brief restatement of his contentions as I understand them. The Marshall Court, he maintains, took a position of judicial objectivity in the slavery cases, just as it did in the areas of nationalism and capitalism. In the latter areas, however, judicial objectivity did not get in the way of a bold use of lawmaking discretion. What troubled Mr. Roper was that the Court did not use the same boldness and discretion in the slave cases to strike a blow for freedom. This inconsistency took him behind the pages of the reports in search of judicial motive and strategy. What he found was a Court divided over the moral issue of slavery, all too united on the sanctity of property rights, and uniformly conscious of the strategic necessity to preserve the appearance of unity and avoid a confrontation with Congress. A consideration of these factors led Mr. Roper to emerge with a highly refined interpretation of "judicial objectivity." It was, he contends, a modus operandi, a strategic device that "salved the conscience of the Court," disguised its internal division over slavery, and avoided decisions on slavery that would bring retaliation from Congress. While judicial objectivity served the Court in these ways, it also "legitimated" slavery.

There is much in Mr. Roper's argument to agree with. The Marshall Court, it seems clear, did not entirely escape the issue of slavery. The Justices were divided on the morality of the issue. There is no reason to doubt that the Marshall Court was aware of its institutional vulnerability in slavery cases, as it was in all other matters that came before it. And the Court did take a position of "judicial objectivity" in the slavery cases. The confrontation of the Court with slavery, modest though it may have been, did in some respects prefigure the more brutal dilemma that faced the Taney Court. The Justices, like other thoughtful Americans, must have sensed the enormity of the issue.

Despite my agreement with these points, I find myself holding back from the final conclusion about judicial behavior in the slavery cases. The disquieting notes are Mr. Roper's general approach to "judicial objectivity" and the implications of this approach for key portions of his argument. Let me explain. I argued above that an adequate assessment of judicial behavior would take into account the limits on judicial action imposed by the law-those limits set by, among other things, the nature of the Court's jurisdiction, the lawmaking potential of the cases before it, indeed, the extent of lawmaking discretion allowed the Court by the whole system of government within which it worked. Basic to a full understanding of the Marshall Court on slavery, then, is a consideration of the range of the Court's discretion in the specific slavery cases that came before it. Given the kind of legal questions before the Court, what could it do about slavery? 
Without establishing what the Court could do, it is impossible to say why it did what it did.

Mr. Roper does not ignore the problem, but there is some vagueness and inconsistency in his treatment of it. He notes that the slavery cases before the Marshall Court by their nature circumscribed the Court's action. Yet he goes on to argue that those cases gave the Court real discretion in the matter of slavery: It had a choice between freedom and property rights; between morality and institutional self-preservation. Indeed, Mr. Roper's assertion that the Court "legitimated" slavery leads strongly to the conclusion that it had substantial discretion and power. The assumption that the Court had the power of choice in the slavery cases is also reflected in Mr. Roper's conclusion about "judicial objectivity." When the Court protests that it is following the law, Mr. Roper doubts its word. "Judicial objectivity," then, is viewed as a mode of operation, a strategy that, instead of being a substantial conditioning factor in the Court's slavery decisions, becomes a technique by which the Court circumvents real alternatives and meaningful choice.

The evidence presented, in my opinion, is not sufficient to sustain this part of Mr. Roper's argument. Specifically, the evidence does not show that the Marshall Court had sufficient alternatives in the slavery cases to reveal judicial motivation. Only three Marshall Court cases dealing with slavery are discussed at any length: Queen v. Hepburn, ${ }^{5}$ The Antelope, ${ }^{6}$ and McCutchen v. Marshall.? The first two seem to be the key cases. Three other cases are noted but not discussed. ${ }^{8}$ The cases discussed, as Mr. Roper observes, were not leading cases: None dealt with constitutional questions; none with fugitives or slavery in the territories. Small cases are sometimes as revealing as leading cases, and Mr. Roper makes them talk; but still I doubt that they can carry the full weight of his conclusions.

Take Queen v. Hepburn. This case reveals, as do dozens of others, such as those in Helen Catterall's collection of cases relating to slavery, ${ }^{\circ}$ how callously the law dealt with human beings. It is saddening to see one of our national heroes troubling over the common law doctrine of hearsay evidence when a man's freedom is at stake. But the real tragedy is that the Court and its Chief Justice were part of a legal system that permitted a man's freedom to hinge on a minor point of common law, or the interpretation of a will, or a promissory note, or a clumsily drafted provision in a state statute. In short, the system of law of which the Court itself was but a part did not permit the Court to consider slavery per se. An opposite

5. II U.S. (7 Cranch) 290 ( 1813 ).

6. 23 U.S. (Io Wheat.) 66 (1825).

7. 33 U.S. (8 Pet.) 220 ( 1834 ).

8. Wood v. Davis, II U.S. (7 Cranch) $27 x$ (I8I2); Scott v. Negro Ben, IO U.S. (6 Cranch) 3 (I810); Scott v. Negro London, 7 U.S. (3 Cranch) 324 (I806).

9. Judiciar Cases Concerning AMerican Slavery and the Negro (5 vols. 1926-37). 
decision in Queen v. Hepburn would not have endangered the institution of slavery, for it was rooted in the laws of Maryland and other slave states that the Court was bound to recognize. In the three other cases mentioned but not discussed, the Court was equally circumscribed in what it could do. The questions before the Court on appeal in Scott v. Negro London ${ }^{10}$ and Scott v. Negro Ben ${ }^{11}$ concerned the interpretation of minor provisions of state laws regulating the importation of slaves. Wood $v$. Davis ${ }^{12}$ turned on the effect of a previous case holding the petitioner's mother free. In none of these cases was the constitutionality or morality of slavery itself before the Court.

What about the better known case of The Antelope? Was the decision in this case also an instance of feigned objectivity? Mr. Roper himself seems at times to take seriously the Court's protestations of objectivity in that case; and there is good reason to do so. The Court, according to existing law, had little alternative. As Marshall made clear, the only course open to the Court under the prevailing principles of international law was to respect the property rights given Spanish citizens by their own law. There was distressingly little law on the other side, and Story's opinion on circuit in United States v. La Jeune Eugénie ${ }^{13}$ could not make up the deficiency. Another difficulty with Mr. Roper's assertion that the Court merely pretended judicial objectivity in The Antelope is that the reasons he cites for its doing so in the other slavery cases were absent here. The Justices may have been divided on the morality of slavery, ${ }^{14}$ but they agreed on the moral evil of the slave trade. And certainly the Court had little to fear from Congress on the subject, since Congress had already gone on record against the trade by making it piracy. Whatever the Court's alternatives were in The Antelope, its real powers were decidedly limited. Its decision could have had little effect on the international law concerning the slave trade. The decision, on the other hand, did not touch the domestic institution. In fact, the Court's decisions on the slave trade had all too little real impact on the trade itself, as its continuance up to the Civil War suggests.

Let me sum up my disagreement with Mr. Roper. He seems to be saying that, because the Marshall Court took policymaking liberties with the law in some areas, it could do so in other areas as well. Judicial objectivity appears to be like virginity: Either she is or she isn't. Now, I am not insisting on the judicial virginity of the Marshall Court. After Marbury v. Madison, ${ }^{15}$ Fletcher v.Peck, ${ }^{18}$ and $M c$ Culloch v. Maryland, ${ }^{17}$ that would be a precarious

Io. 7 U.S. (3 Cranch) 324 (1806).

II. Io U.S. (6 Cranch) 3 (1810).

12. II U.S. (7 Cranch) 271 (1812).

13. 26 F. Cas. 832 (No. 15,55I) (C.C.D. Mass. 1822 ).

14. Roper, supra note 3, at 532-34.

15. 5 U.S. (I Cranch) 137 (1803).

I6. Io U.S. (6 Cranch) 87 (1810).

17. 17 U.S. (4 Wheat.) 316 (1819). 
assertion. But I would like to suggest that a nonvirgin is not necessarily a loose woman. Maybe protestations of judicial objectivity were used in cases involving nationalism and capitalism as a screen for creative policymaking. But there are occasions when the Court is limited in what it can do. Sometimes the law is clear and the Justices' obligation to it inescapable. Finally, of course, it is possible that judicial objectivity and policymaking are not mutually exclusive. But so far as the slavery cases of the Marshall period are concerned, I am inclined to think that they presented the Court with very little real discretion.

If my argument is correct, two things follow. First, if the Marshall Court did not have substantial lawmaking discretion in the slavery cases, it would be misleading to say that it "legitimated" slavery. That odious accomplishment was the work of colonial and state law (as Mr. Roper himself noted) and, as the Abolitionists claimed, the Constitution of the United States. ${ }^{18}$ Second, until the Court confronted slavery directly, the motives of the Justices were likely to remain inchoate and nebulous; historical assessment of them is bound to be inconclusive.

Mr. Burke's article complements Mr. Roper's. Again, in the Cherokee cases, the Court faced a basic moral issue. Again it was under pressure from a hostile Congress and Executive and circumscribed by its institutional limitations. The traditional interpretation is that the Court had to bow to its enemies. The Indian cases, the story goes, marked the climax of a progressive deterioration in the power and prestige of the Marshall Court that began in the mid-I820's. Not even a great judicial strategist like John Marshall could save the day. Mr. Burke revises this dark picture in several respects. To be sure, he does not try to make 1832 into another 1819 . But he does show that the Indian cases were not unqualified defeats for the Court. Indeed, if he is correct, the Court not only salvaged its prestige and kept its morality and its nationalist legal principles intact, but even managed to strike a retaliatory political blow against the Jacksonians. The Chief Justice, despite age and illness, had not, it would seem, lost his toughness and caginess. The moral of the story, as Mr. Burke draws it, is that judicial statesmanship is not always preoccupied with or precluded by the science of the law, nor is it always apparent on the face of the court reports. If, as I argue, judicial objectivity and judicial limitations constrained the Court in the slavery cases, it did not wholly do so, says Mr. Burke, in the Cherokee cases.

The judicial maneuvering Mr. Burke discovers is as complex and subtle as any in the Court's great victorious moments. Take for example the legal footwork in the first Indian case, Cherokee Nation v. Georgia. ${ }^{19}$ Marshall

18. See Lynd, The Compromise of $1787,8 \mathrm{I}$ Por. Scr. Q. 225 (1966); Lynd, Beyond Beard, in Towards a New Past: Dissenting Essays in American History (B. Bernstein ed. I968).

19. 30 U.S. (5 Pet.) I (I83I). 
had said no before when he meant yes, but I do not recall that he ever did it by way of encouraging a dissent from his own majority opinion. Moreover, as Mr. Burke has it, Marshall not only manipulated the majority and dissenting opinions in such a way as to invite new litigation but, thanks to his own dicta and Thompson's dissent, made it apparent what the decision of the Court would be in that litigation. And by skillfully maneuvering between the majority and dissenting camps, the Chief Justice may well have kept the existing split on the Court from widening further.

Another intriguing part of Mr. Burke's article has to do with the political repercussions of the Court's decisions, especially in the second case, Worcester v. Georgia. ${ }^{20}$ Marshall's victory, if that is the right word, in fact had a more immediate impact on politics than it did on law, since the decision was never enforced, since, in fact, the Court never ordered it enforced. One wonders, for example, whether the Indian cases were planned by antiJackson leaders as part of the overall campaign strategy in 1832 . The political issues raised by the second Indian case seem so exactly suited to the needs of the emerging Whig party that it is hard to imagine that the Whigs' use of them was incidental or accidental. By 1832 the Jacksonians were well on their way to identifying themselves with democracy and the common man and casting their opponents as immoral, monied aristocrats. The Indian cases and Jackson's response to them worked to turn the moral tables on the President and his party. In addition, they buttressed anti-Jackson propaganda that depicted the President as a tyrant full of contempt for the Constitution, the Supreme Court, and law and order in general. The Cherokee cases did not turn the political tide, but there is considerable evidence that they left a powerful impression.

There is another reason for suspecting that the Court was being used as part of a coordinated political effort. The legal elite that masterminded the Cherokee litigation was, at the same time, battling the Jacksonians on other fronts. Wirt, as Mr. Burke noted, was the Anti-Masonic candidate who opposed Jackson in I832. Sergeant and Webster were generals in the army of Nicholas Biddle in the Bank War. Sergeant was the major-domo of the Bank's legal house; Webster was the Bank's political-legal advisor who, along with Clay, turned the Bank recharter into a campaign issue for 1832 . Webster was the leading constitutional spokesman against states rights and nullification. Chancellor Kent and Justice Joseph Story, both strong supporters of the Cherokees, were also quietly enlisted by Webster against Jackson in the Bank War and the nullification controversy. ${ }^{21}$ Indeed, the concerted effort by the elite portion of the legal profession in the Indian cases

20. 3 I U.S. (6 Pet.) 515 ( 1832 ).

2x. See Newmyer, Daniel Webster as Tocqueville's Lawyer: The Dartmouth College Case Again, is Am. J. Legal Hist. I27 (1967). 
calls to mind Tocqueville's legal aristocracy. ${ }^{22}$ The Cherokee litigation in behalf of morality, nationalist constitutional principles, and Whig politics is remarkably similar to the pattern of organized interest-group litigation discovered by Peter Magrath ${ }^{23}$ in Fletcher v. Peck, ${ }^{24}$ except that the issue for which the judicial process was used was political rather than economic.

To sum up briefly, Mr. Burke calls attention to wide-ranging political consequences of the Indian cases that were heretofore not apparent. $\mathrm{He}$ throws new light on the tactics by which Marshall led the Court to a decision that was legally and morally sound and, at the same time, politically pleasing to the conservatives on the Court. The Indian cases were not, then, the unmitigated defeats for the Court that they are sometimes depicted as being.

Marshall accomplished these results without cynically disregarding the law on the question of jurisdiction, or abandoning his respect for the institutional procedures of the Court. To put it another way, Marshall's genius, in this case as in others, was not that he abandoned the framework of the law, but that the legal framework allowed discretion and choice sufficient for statesmanship. The message is that the Supreme Court can affect politics without ceasing to be a court of law; the burden of scholarship then is to understand both the political and the legal dimensions of the Court.

The articles of Mr. Burke and Mr. Roper deal separately with the problem of the relationship between law and morality. Taken together, they also yield some insights into that relationship. Permit me, then, to conclude with a brief attempt at a synthesis. Reading these papers side by side, I wished that Mr. Roper had included slavery and the Taney Court in his analysis. For the really instructive comparison, I think, is between the Cherokee Indian cases and Dred Scott $v$. Sandford. ${ }^{25}$ The immediate legal impact of both cases was negligible. Both cases were bound up in presidential politics. Both crystallized internal division on the Court. Both divided the nation along a moral axis. And both permitted the Court discretion within the law sufficient to measure judicial motive. When juxtaposed, they permit us to speculate a bit about the challenging question Mr. Roper raised: Why did the Court stand up for morality in the case of the Indian and not in the case of the Negro slave?

Mr. Roper and Mr. Burke together suggest at least a partial answer to the question. In the case of the Indians, the Justices could indulge their moral principles without having to abandon their attachment to property rights. Not so in regard to slavery. And when morality and property rights confronted one another in Dred Scott, morality gave way.

22. I DemOCRACY IN AMERICA 282-90 (Vintage ed. I959).

23. See P. Magrath, Yazod: LAw and Politics in the New Republic: The Case of Fletcher v. PECK (1966).

24. Io U.S. (6 Cranch) 87 (1810).

25. 60 U.S. (19 How.) 393 (1857). 
Now it might be argued with some truth that the Marshall Court was in no way responsible for what the Taney Court did in Dred Scott v. Sandford. Yet, when the Taney Court made the Constitution protect property rights in slaves, when it made the law serve the economic interests of an expansive, agrarian, slave-holding capitalism, it was clearly acting in the tradition established by the Marshall Court. The irony is that it was not so much the slavery cases under Marshall that paved the way for Dred Scott as it was the Court's dedication to the protection of property rights and its use of the law to release the energies of dynamic capitalism.

One might conclude that when push came to shove, the antebellum Court was a feeble instrument of morality. But is not the point more truly that the Court did in fact represent and further the prevailing morality of the United States? This morality identified property with liberty and subscribed to the notion that individual freedom was realized in economic endeavor. The Court gave constant sanction to this association of property and liberty. It did more. It built a framework of law and order within which the free enterprise morality could function most efficiently and generate its own raison d'etre. In this jurisprudential cosmology, law became morality; morality was the law. It took Dred Scott to drive home the point, one for which the Abolitionists had long contended, that law and morality were sometimes distinguishable-that they could be separate and unequal. 